\title{
GOOD GOVERNANCE IMPLEMENTATION TOWARDS SUB-DISTRICTS GOVERNANCE SERVICE: A CASE STUDY OF SIDOARJO DISTRICTS, INDONESIA
}

\author{
Suprayitno \\ Study of Law Science and Development, Post-graduate School, \\ Airlangga University, Indonesia \\ E-mail: ontiyarpus@gmail.com
}

\begin{abstract}
The enactment of Law \#25 of 2009 on Public Service brings great consequences for the government as a public service to the community. The quality of the public service is often regarded as a mirror of the quality of the bureaucracy in general. The public service is closely related to system, apparatus resources and more staple is the paradigm of thinking behind the process it given to community. The one of spearhead the public service to the community is village. This study attempted to describe the condition of conducting the current administration and see how the village government's effort in implementing the principles of good governance in providing service to the community. The constraints of personnel / apparatus competence and disproportionally budget as well as a challenge for the village to remain able to provide service to the community in order to realize good governance.
\end{abstract}

\section{KEY WORDS}

Good governance, public service, village, government.

The implementation of Law number 25 of 2009 about Public Service creates a great consequence for government as the servant of society. The quality of public service from government is the representation of bureaucracy quality in general. The public service is very close to a system, the apparatus empowerment and the more important aspect is the cognitive paradigm which becomes backgrounds of service process given to society.

The region autonomy which is already implemented long enough could not able to improve the quality service towards society. The apparatus of state bureaucracy in Indonesia is not yet in full consciousness about the importance of giving best service as the representation to civil serve.

Public service is the bridge of how the State (the bureaucratic apparatus) performs its functions in relation to the society (people), so the effort to reform the public service in accordance with the socio-cultural character of society or as desired by the public, should at least be a government issue to continue to be considered in order to be the best solution.

The reform of the public service paradigm is a change in the pattern of service delivery from the former oriented to the government is now changing towards the needs of society.

Thus, the improvement of civil participation in public service is an important factor.

At least, there are three reasons as trigger to raise public service reformation in order to achieve the good governance principle. First, the fixation of working performances of the apparatus maintained directly by stakeholders, they are the society, government, and economic actors.

Secondly, public service is one of three good governance materials which interact with people intensively. It is the implementation of public service, government, society, and economic actors. Thirdly, the principles as representation of good governance are already easier and exist through public service.

From those phenomena, there is a movement which try to portray the reflection of the smallest public service area which is village, it is very interesting topic to examine such phenomenon. Village, as the ultimate and the front line of country to count on its people, becomes a suitable target for implementation of good governance through public service. 
Research Problem. From background of study above, the research problem of this study will be "the role of head of village in public service to realize good governance in Sidoarjo regency government". The problem study raised two research questions as follow:

- How is the implementation system of village governance in Sidoarjo regency?

- How is the implementation of good governance through public service in Sidoarjo regency?

Purpose of Study. Along with the background and problems of study, the objectives of study are as follow:

- To analyse the implementation system of village governance in Sidoarjo regency;

- To analyse the implementation of good governance through public service in Sidoarjo regency.

Significance of Study. From the two objectives above, there will be some purposes of study as follow:

- In theoretical purposes, the study is aimed to improve and advance the knowledge of the related study or case. It could be also add the academicals references in accordance with the role of head of village to realize good governance;

- Practically, this study will help Sidaorjo regency as their reference and plan to improve the role of head of village in the implementation of public service towards good governance;

- As reference for the next research.

\section{LITERATURE REVIEW}

The establishment of village governance is stated in the decision of Ministry of home Affairs number 65 of 1999 about the general instruction of village establishment. Different from Law number 5 of 1979 about Village governance, in the Decision of Ministry of home Affairs number 65 of 1999 about the general instruction of village establishment, it is stated that village is established in the area of city within the condition of its width, population, potency, and social culture condition.

By the publication of Law number 32 of 2004 about region regulation, the position of village governance is ascended from authority of sub-district governance to be Regency/City in the environment of Sub-district working area.

The public bureaucracy must be able to provide more professional, effective, simplified, transparent, punctual, responsive and adaptive public service. The service will also improve the quality life and individual capacity as people will able to determine its own future.

Professional public service is a service within accountability and responsibility from state apparatus.

Governance is defined as the mechanisms, practices and procedures of governance and citizens governing resources and solving public problems. In the concept of governance, the government only becomes one of the actors and is not always a decisive actor. The implications of the role of government as development and service providers and infrastructure will shift into the driving force of creating an environment that is able to facilitate other parties to the other communities.

It could be concluded that good governance is a development of management implementation which is solid and concerned with the basic principles of democracy and efficient market, to prevent the act of political/administrative corruption and mal financial allocation, to realise the budget discipline and the establishment of legal politics and political framework for economical growth.

In the document of United Nation Development Programme (UNDP) policy, it states several characteristics of good governance as follow: Participation; Rule of law; Transparency; Responsiveness; Consensus Orientation; Equity; Efficiency and effectiveness; Accountability; Strategic vision.

The actors, in the context of public service improvisation, regard the principles of good governance, it becomes very important. The principals of good governance are: 
Transparency; Accountability of Public Service; Public Service Responsiveness; Fairness equality; Efficiency \& Effectiveness; Public Service participation.

\section{METHODS OF RESEARCH}

This study uses descriptive qualitative method. Descriptive research is a research which is conducted to describe something in significance place and time.

Qualitative method defined as social study method which collect and analyse the data in the form of text (written or spoken). The method could also analyse the behaviour actions of humans. The researcher does not use count nor quantitative technique to collect them. That is why; numbers are rarely served as data in this study.

The sample classification technique used in this study is known as purposive sample. It is a technique to choose the sample based on their capability to answer and respond towards the case study of the experiment. Thus, the sample will able to provide more information than some random samples as representation of general population. The respondents are as follow:

1. The informant respondents are:

- Head of Taman sub-district;

- Head of Bebekan village;

- Head of Ketegan village;

- Head of Wonocolo village;

- Head of Ngelom village;

- Head of Kalijaten village;

- Head of Taman village;

- Head of Geluran village;

- Head of Sepanjang village.

2. The respondents of local people which apply for some public service certification. It will be 40 people in total which means 5 people for each sub-district.

The technique to collect data used in this study is using field observation and in-depth interview instruments.

\section{RESULTS OF STUDY}

Village government implementation system in Sidoarjo Regency:

Explicitly, the position of urban village is not part of local apparatus anymore, but it is already under the umbrella of sub-district governance. The law enforcement of village existence in Sidoarjo regency is stated in several laws as follow:

- Local regulation of Sidoarjo regency number 19 of 2011 about the establishment of society council in villages;

- Local regulation of Sidoarjo regency number 11 of 2016 about the establishment and the composition of local apparatus in Sidoarjo regency.

- Regulation Sidoarjo regent number 91 of 2016 about position, organisation composition, duty and function, and the working procedure in sub-districts of Sidoarjo regency.

From eighteen sub-dictricts in Sidoarjo regency, the urban villages only found on four sub-districts which are in Sidoarjo, Porong, Taman, and Krian sub-district. In total, there are thirty one urban villages of Sidoarjo regency as follow in Table 1.

Concerning with urban village empowerment council (LPMK), hamlet, neighbourhood, empowerment and prosperous activators (PKK), Young villagers' community, and another civil society are established by the Law of local regulation Sidoarjo regency number 19 of 2011 about the instruction of urban village and village civil society establishment.

From working procedure aspect, urban village already has standard operation procedure (SOP) to support the duty and implementation of law in urban village level. Coordination is the principle of external working procedure and local apparatus organisation 
(OPD). If there is any problem out of urban village authority, the urban village must report and sub ordinate with the institution who possessed the authority to determine and concern about the problem.

Table 1 - Urban Villages of Sidoarjo Regency

\begin{tabular}{|c|c|c|c|}
\hline No. & $\begin{array}{c}\text { Sub- } \\
\text { District }\end{array}$ & Urban Village & Annotation \\
\hline 1. & \multirow{3}{*}{ Krian } & Kemasan & - \\
\hline 2. & & Krian & - \\
\hline 3. & & Tambak Kemerakan & - \\
\hline 4. & \multirow{8}{*}{ Taman } & Sepanjang & - \\
\hline 5. & & Bebekan & - \\
\hline 6. & & Ketegan & - \\
\hline 7. & & Wonocolo & - \\
\hline 8. & & Ngelom & - \\
\hline 9. & & Kalijaten & - \\
\hline 10. & & Taman & - \\
\hline 11. & & Geluran & - \\
\hline 12. & \multirow{14}{*}{ Sidoarjo } & Bulusidokare & - \\
\hline 13. & & Celep & - \\
\hline 14. & & Cemengkalang & - \\
\hline 15. & & Gebang & - \\
\hline 16. & & Lemahputro & - \\
\hline 17. & & Magersari & - \\
\hline 18. & & Pekauman & - \\
\hline 19. & & Pucang & - \\
\hline 20. & & Pucanganom & - \\
\hline 21. & & Sekardangan & - \\
\hline 22. & & Sidokare & - \\
\hline 23. & & Sidoklumpuk & - \\
\hline 24. & & Sidokumpul & - \\
\hline 25. & & Urangagung & - \\
\hline 26. & \multirow{6}{*}{ Porong } & Gedang & - \\
\hline 27. & & Jatirejo & Proposed for revocation because of natural disaster known as "Lumpur Lapindo" \\
\hline 28. & & Juwetkenongo & - \\
\hline 29. & & Mindi & Proposed for revocation because of natural disaster known as "Lumpur Lapindo" \\
\hline 30 & & Porong & - \\
\hline 31. & & Siring & Proposed for revocation because of natural disaster known as "Lumpur Lapindo" \\
\hline
\end{tabular}

Urban village is also already possessed standard service documents. The urban village must periodically socialise and inform people about the procedure of some administration process in small limited conference with its people. They also could use brochure, banner or another media to tell people some important information.

From the field observation, generally, the public service implementation is well served toward society.

In general, technology and infrastructure service in Sidoarjo District is sufficient. Because, since the existence of Monitoring and Evaluation of some of the authority of the Regent to the Camat (Regent of Sidoarjo Regulation Number 78 of 2008 on the Delegation of some of the Regent's Authority to the District Head and Regulation of Sidoarjo Number 18 of 2009 on Guidelines Technical Assignment of Part of the Central Government's Authority to the Head of Sub-district and the Regulation of the Minister of Home Affairs Number 4/2010 on the Integrated Service Guidelines of Kecamatan / PATEN) in 2014, Sidoarjo District Government requires the Village Administration to prepare Standard Operation Procedure (SOP) (SP), including the fulfilment of technology and minimal infrastructure to support the service.

The position of urban village as sub-district governance causes inability of urban village to possess its own Budget Implementation Document (DPA). The document is already attached along with DPA sub-district.

Good governance in urban village governance service. Good governance implementation towards public service is one of movement commenced by Sidoarjo regency government in order to accomplish administration law enforcement. Administration law 
approach, according to Philippus M.Hadjon, consists of three approaches as follow: Government Power Approach; Right Based Approach; Functionaries Approach.

Law number 23 of 2014 about local government; it classified the duty of government based on its authority. Explicitly, the position of urban village is not part of local apparatus anymore, but it is already under the umbrella of sub-district governance. From the regulation change, the position of urban village based on law number 23 of 2014 about local government, the authority change is very wide. In the other hand, stated in law number 32 of 2004 about local government, it decides the position of urban village as village device position (article 120 act 2).

The explanation above becomes proves that urban villages is an entity/part of subdistrict governance which possesses a right to serve the public. That is why, the urban villages as servant of society is mandatory to complete general principles of good governance (known as AUPB in Indonesia).

The implementation of good governance principles in serving the public service is part of human Right complement as stated in Article 28I act (4) Fundamental Law of Indonesian Republic of 1945 which firmly states that protection, improvement, enforcement, and complement of human Right are responsibility of government.

Good governance is very close to human rights as it is connected by three fundamental duties of government.

General principles of good governance in serving the public needs of urban village as part of local governance or as the administrators of local government is already regulated at least at six laws as follow: Law number 23 of 2014; Law number 25 of 2009; Law number 28 of 1999 about state establishment which is clean and free from corruption, collusion, and nepotism; Law number 30 of 2014 about State Administration; Law number 37 of 2008 about Ombudsman; Law number 5 of 2014 about Civil State Apparatus (known as ASN in Indonesia).

From all of six laws which control the good governance principle, they are all connected with the authority and duty of government in the implementation of urban village public service. There are eight principles to establish good governance; they are law certainty, public priority, transparency, quality, austerity, authority effectiveness, good service and justice principle. By holding to those principles, the good governance law will be well established.

The implementation of good governance principles (AUPB) in the administrative services of urban village, based on the approach of functional aspect, is the a step and action of the government from the perspective of the behaviour of the apparatus while implementing the regulations governing the service to the community in accordance with the authority of stakeholders in performing the task in charge government service to the community.

The comprehensive manifestation of the basic values and codes of conduct and code of conduct in the administrative offices of urban village administration is one of the keys to the achievement of good governance in the service of village administration to the community.

Table 2 - Details of the respondents

\begin{tabular}{|c|c|c|c|c|c|c|c|c|}
\hline \multicolumn{3}{|l|}{ Sex } & \multicolumn{3}{|c|}{ Education Level } & \multicolumn{3}{|l|}{ Occupation } \\
\hline & Total & Precentage & & Total & Precentage & & Total & Precentage \\
\hline \multirow{3}{*}{ Male } & \multirow{3}{*}{12} & \multirow{3}{*}{$30 \%$} & Elementary & 4 & $10 \%$ & $\begin{array}{l}\text { Businessman/Entrepreneur, } \\
\text { Private Employee }\end{array}$ & 11 & $27,5 \%$ \\
\hline & & & Junior High & 3 & $7,5 \%$ & Civil Servant & 5 & $12,5 \%$ \\
\hline & & & $\begin{array}{l}\text { Senior } \\
\text { High }\end{array}$ & 15 & $37,5 \%$ & Police or Soldier Officer & 4 & $10 \%$ \\
\hline \multirow{4}{*}{ Female } & \multirow{4}{*}{28} & \multirow{4}{*}{$70 \%$} & Diploma & 9 & $22,5 \%$ & Driver/Pedicabman & 2 & $5 \%$ \\
\hline & & & Bachelor & 7 & $17,5 \%$ & Students & 3 & $7,5 \%$ \\
\hline & & & \multirow{2}{*}{ Master } & \multirow{2}{*}{2} & \multirow{2}{*}{$5 \%$} & Housewife & 8 & $20 \%$ \\
\hline & & & & & & Retired Civil Servant & 7 & $17,5 \%$ \\
\hline
\end{tabular}


Implementation of Good Governance towards Urban Village Service. From those principles and approaches of good governance, the experiment of this study is limited to three major principle of good governance which are Participation, transperancy, and accountability principle. The 40 respondents which are people of urban villages who are taking care of their state affairs. The details of the respondents are shown in Table 2.

From the table above, we could assume that the respondents are filled with more female samples about $70 \%$. Next, the majority of education level is held by Senior high School level while the occupation column is controlled by Businessman/Entrepreneur, Private Employee, it gains 27,5\%.

Implementation of Participation Principle in Urban Village Service. According to the result from interview and observation process, it discussed about the contribution of society in establishing an event or a program with government within the service provided by the urban village governance. The plaint and complaint towards urban villages service about the contribution of society in some of urban village program, it could be synthesised in $\mathrm{N}$ : quantity, \%: percentage.

Table 3 - Contribution of society in some of urban village programs

\begin{tabular}{|c|c|c|c|c|c|c|c|c|c|c|c|}
\hline \multicolumn{2}{|l|}{ Participation Aspect } & \multicolumn{8}{|c|}{ Service Type } & \multicolumn{2}{|c|}{ Total } \\
\hline \multirow{6}{*}{ The society is included in the program } & \multirow{2}{*}{ Criteria } & \multicolumn{2}{|c|}{ ID Card } & \multicolumn{2}{|c|}{ Family Card } & \multirow{2}{*}{\multicolumn{2}{|c|}{ Certificate }} & \multicolumn{2}{|c|}{ Other } & \multirow{2}{*}{$\mathrm{N}$} & \multirow{2}{*}{$\%$} \\
\hline & & $\mathrm{N}$ & $\%$ & $\mathrm{~N}$ & $\%$ & & $\%$ & $\mathrm{~N}$ & $\%$ & & \\
\hline & Always & 3 & 7,5 & 4 & 10 & 2 & 5 & 1 & 2,5 & 10 & 25 \\
\hline & Often & 10 & 25 & 6 & 15 & 3 & 7,5 & 3 & 7,5 & 22 & 55 \\
\hline & Rarely & 4 & 10 & 2 & 5 & 1 & 2,5 & 1 & 2,5 & 8 & 20 \\
\hline & Never & 0 & 0 & 0 & 0 & 0 & 0 & 0 & 0 & 0 & 0 \\
\hline \multirow{4}{*}{ The Policy Decision Contribution of Society } & Always & 0 & 0 & 0 & 0 & 0 & 0 & 0 & 0 & 0 & 0 \\
\hline & Often & 2 & 5 & 1 & 2,5 & 3 & 7,5 & 1 & 2,5 & 7 & 17,5 \\
\hline & Rarely & 4 & 10 & 3 & 7,5 & 2 & 5 & 1 & 2,5 & 10 & 25 \\
\hline & Never & 12 & 30 & 4 & 10 & 5 & 12,5 & 2 & 5 & 23 & 57,5 \\
\hline \multirow{4}{*}{ The Plaint elated to the Service } & Always & 0 & 0 & 0 & 0 & 0 & 0 & 0 & 0 & 0 & 0 \\
\hline & Often & 0 & 0 & 0 & 0 & 0 & 0 & 0 & 0 & 0 & 0 \\
\hline & Rarely & 14 & 35 & 6 & 15 & 2 & 5 & 0 & 0 & 22 & 55 \\
\hline & Never & 8 & & 7 & & 2 & & 1 & & 18 & 45 \\
\hline
\end{tabular}

The table above shows participation of society towards the type of service type in urban village, the details are:

- People are often included and participate in government program up to 55\%;

- For policy decision participation, the highest point is found in 'Never' category up to $57,5 \%$;

- In accordance with, the plaint and complaint of service, the highest answer is 'Rare' column up to $55 \%$.

The implementation of participation principle must be supported with the discipline of society to give their contribution and obey the procedure in every demand of their affair. People must complete the requirement documents before; they will earn their right as the procedure is completed.

Transparency Principle. Transparency principle is much related with the effectiveness of the information provided by local government to the society about public service.

Based on the results of observations and interviews, their responses to the dissemination of information to the public is related to service procedures performed by nongovernment elements, the effectiveness of delivering information about the Village service through media brochures / leaflets, media Radio, Newspapers and internet, can be seen in Table 4.

From the table above, we could conclude that: the participation of Non-Government element is not yet effective to distribute the information into society, the amount of $67,5 \%$ is not high enough; the most effective media, according to the respondents, is by using brochure / leaflet media which is $62,5 \%$. 
Table 4 - Effectiveness of delivering information

\begin{tabular}{|c|c|c|c|c|c|c|c|c|c|c|c|}
\hline \multicolumn{2}{|c|}{ Transparency Aspect (Information Distribution) } & \multicolumn{8}{|c|}{$\begin{array}{l}\text { The Respondents Hear/See the Information } \\
\text { Distribution }\end{array}$} & \multicolumn{2}{|c|}{ Total } \\
\hline \multirow{6}{*}{$\begin{array}{l}\text { Non-Government Elements } \\
\text { Participation }\end{array}$} & \multirow{2}{*}{ Criteria } & \multicolumn{2}{|c|}{ Always } & \multicolumn{2}{|c|}{ Often } & \multicolumn{2}{|c|}{ Rare } & \multicolumn{2}{|c|}{ Never } & \multirow{2}{*}{$\mathrm{N}$} & \multirow{2}{*}{$\%$} \\
\hline & & $\mathrm{N}$ & $\%$ & $\mathrm{~N}$ & $\%$ & $\mathrm{~N}$ & $\%$ & $\mathrm{~N}$ & $\%$ & & \\
\hline & Very High & 0 & 0 & 0 & 0 & 0 & 0 & 0 & 0 & 0 & 0 \\
\hline & High & 2 & 5 & 6 & 15 & 0 & 0 & 0 & 0 & 10 & 25 \\
\hline & Low & 4 & 10 & 2 & 5 & 1 & 2,5 & 1 & 2,5 & 27 & 67,5 \\
\hline & Very Low & 0 & 0 & 3 & 7,5 & 0 & 0 & 0 & 0 & 3 & 7,5 \\
\hline & & & & & & & & & & & \\
\hline \multirow{4}{*}{$\begin{array}{l}\text { Media Brochure/leaflet } \\
\text { Effectiveness }\end{array}$} & Very Effective & 0 & 0 & 0 & 0 & 0 & 0 & 0 & 0 & 0 & 0 \\
\hline & Effective & 4 & 10 & 18 & 45 & 3 & 7,5 & 0 & 0 & 25 & 62,5 \\
\hline & Less Effective & 4 & 10 & 3 & 7,5 & 2 & 5 & 1 & 2,5 & 10 & 25 \\
\hline & Ineffective & 0 & 0 & 2 & 5 & 3 & 7,5 & 0 & 0 & 5 & 12,5 \\
\hline \multirow{4}{*}{ Radio Effectiveness } & Very Effective & 0 & 0 & 0 & 0 & 0 & 0 & 0 & 0 & 0 & 0 \\
\hline & Effective & 0 & 0 & 0 & 0 & 0 & 0 & 0 & 0 & 0 & 0 \\
\hline & Less Effective & 14 & 35 & 6 & 15 & 2 & 5 & 0 & 0 & 22 & 55 \\
\hline & Ineffective & 8 & 20 & 7 & 17,5 & 2 & 5 & 1 & 2,5 & 18 & 45 \\
\hline \multirow{4}{*}{ Newspaper Media Effectiveness } & Very Effective & 0 & 0 & 0 & 0 & 0 & 0 & 0 & 0 & 0 & 0 \\
\hline & Effective & 0 & 0 & 8 & 20 & 2 & 5 & 0 & 0 & 10 & 25 \\
\hline & Less Effective & 14 & 35 & 6 & 15 & 2 & 5 & 0 & 0 & 22 & 55 \\
\hline & Ineffective & 8 & & 7 & & 2 & & 1 & & 8 & 20 \\
\hline \multirow{4}{*}{ Internet Effectiveness } & Very Effective & 0 & 0 & 0 & 0 & 0 & 0 & 0 & 0 & 0 & 0 \\
\hline & Effective & 0 & 0 & 10 & 25 & 2 & 5 & 0 & 0 & 12 & 30 \\
\hline & Less Effective & 14 & 35 & 6 & 15 & 2 & 5 & 0 & 0 & 22 & 55 \\
\hline & Ineffective & 0 & 0 & 4 & 10 & 2 & 5 & 0 & 0 & 6 & 15 \\
\hline
\end{tabular}

Accountability Principle. Implementation of the principle of accountability relates to the extent of accountability of the urban village government to the community related to the provision of services. The results of observations and interviews to Respondents related to the accountability of urban village service seen through the clarity aspects of service mechanisms and procedures, the timeliness of service and clarity of service costs can be seen in the following table:

Table 5 - Accountability of urban village service

\begin{tabular}{|c|c|c|c|c|c|c|c|c|c|c|c|}
\hline \multicolumn{2}{|l|}{ Accountability Aspect } & \multicolumn{8}{|c|}{ Service Type } & \multicolumn{2}{|c|}{ Total } \\
\hline \multirow{6}{*}{ Service Procedure Clarity } & \multirow{2}{*}{ Criteria } & \multicolumn{2}{|c|}{ ID Card } & \multicolumn{2}{|c|}{ Family Card } & \multicolumn{2}{|c|}{ Certificate } & \multicolumn{2}{|c|}{ Other } & \multirow{2}{*}{$N$} & \multirow{2}{*}{$\%$} \\
\hline & & $\mathrm{N}$ & $\%$ & $\mathrm{~N}$ & $\%$ & $\mathrm{~N}$ & $\%$ & $\mathrm{~N}$ & $\%$ & & \\
\hline & Very Clear & 3 & 7,5 & 4 & 10 & 2 & 5 & 1 & 2,5 & 10 & 25 \\
\hline & Clear & 10 & 25 & 6 & 15 & 3 & 7,5 & 3 & 7,5 & 25 & 62,5 \\
\hline & Less Clear & 0 & 0 & 0 & 0 & 3 & 7,5 & 2 & 5 & 5 & 12,5 \\
\hline & Unclear & 0 & 0 & 0 & 0 & 0 & 0 & 0 & 0 & 0 & 0 \\
\hline \multirow{5}{*}{ Punctuality } & & & & & & & & & & & \\
\hline & Very Clear & 0 & 0 & 0 & 0 & 0 & 0 & 0 & 0 & 0 & 0 \\
\hline & Clear & 0 & 0 & 0 & 0 & 0 & 0 & 0 & 0 & 0 & 0 \\
\hline & Less Clear & 0 & 0 & 0 & 0 & 2 & 5 & 3 & 7,5 & 5 & 12,5 \\
\hline & Unclear & 15 & 37,5 & 16 & 40 & 1 & 2,5 & 1 & 2,5 & 33 & 82,5 \\
\hline \multirow{4}{*}{ Service Cost Transparency } & Very Clear & 0 & 0 & 0 & 0 & 0 & 0 & 0 & 0 & 0 & 0 \\
\hline & Clear & 14 & 35 & 15 & 37,5 & 4 & 10 & 1 & 2,5 & 34 & 85 \\
\hline & Less Clear & 0 & 0 & 0 & 0 & 2 & 5 & 0 & 0 & 2 & 5 \\
\hline & Unclear & 0 & 0 & 0 & 0 & 3 & 7,5 & 1 & 2,5 & 4 & 10 \\
\hline
\end{tabular}

From the table, the conclusions are:

- The service clarity in urban village public service is already high, it is $62,5 \%$;

- The service punctuality in urban village public service is already high, it is $82,5 \%$;

- The service cost transparency in urban village public service is already high; it is $85 \%$ as all public service in urban village is free of cost.

The process and procedure found in urban village public service is followed the SOP (Standard Operational Procedure). The head of urban village is fully responsible to head of sub district. The hierarchical mechanism and the investigation towards public service of urban village are held by head of sub district. 


\section{CONCLUSION AND SUGGESTIONS}

According to the discussion and findings above, there is some conclusions related the implementation of good governance in urban village public service of Sidoarjo regency as follow:

- The state establishment in urban village of Sidoarjo regency follows and obeys the recent regulation of state. The only problem is found on the personal/apparatus and the finance expenditure which is not yet clear.

- The implementation of good governance in urban village public service, in participation, accountability, and transparency, is not yet achieved. There is a problem in punctuality service while people want to arrange their identity card and family card; there is also legality of urban village head signature in administration of land certificates.

Furthermore, some suggestions related to the implementation of good governance in the service of urban village administration in Sidoarjo Regency are as follows:

- The Government of Sidoarjo Regency immediately formulate the Regent Regulation related to consolidation of the urban village capacity, especially, those related to the fulfillment of personnel / apparatus and the occasional rotation of personnel in the urban village employees refreshment.

- So that, the Sidoarjo Regency Government will immediately evaluate the urban village budgeting system to be proportional in accordance with the scope of service and the scope of accountability.

- Government need to be guided and monitored by the institution regularly related to the implementation of services organized by the village administration.

- There must be regular coordination between urban villages; the head must be in line with the relevant agencies concerned with the service of land administration in order to clear the position and responsibility of the head in providing services.

\section{REFERENCES}

1. Sujatmoko, Bentuk Hukum Kerjasama Antar Daerah, Revka Petra, Surabaya, 2016.

2. Mahsun, Mohamad, Pengukuran Kinerja Sektor Publik, BPFE: Yogyakarta, 2006.

3. Muladi, Hak Asasi Manusia, Hakekat Konsep dan Implikasinya, Refika Aditama, Bandung, 2009.

4. Widodo, Joko, Good Governance, Ihsan Cendekia, Surabaya, 2001.

5. Sumarto, Inovasi, Partisipasi dan Good Governance, Yayasan Obor, Bandung, 2011.

6. Savas, E.S, Privatization "The Key To Better Government", New Jersey: Chantan House Publisher Inc, Chatam, 1987.

7. Arif, Syaiful, Pelayanan Publik di Indonesia, Averose Press, Malang, 2008.

8. Purwanto, Erwan Agus, Pelayanan Yang Partisipatif, Gajah Mada University Press, Yogyakarta, 2008.

9. Suratman dan Dillah, Philips, Metode Penelitian Hukum, Alfabeta, Bandung, 2012.

10. Afrizal, Metode Penelitian Kualitatif, PT. RajaGrafindo Persada, Jakarta, 2014.

11. Moh. Nazir, Metode Penelitian, Ghalia Indonesia, Bogor, 2013.

12. Hadjon, Philipus M, Pengantar Hukum Administrasi Indonesia, Gadjah Mada University Press, Yogyakarta, 2005.

13. Dwiyatno, Agus, Mewujudkan Good Governance Melalui Pelayanan Publik, Gajahmada University Press, Yogyakarta, 2008.

14. UNDP. 1997, Tata Pemerintahan Yang Baik Dari Kita Untuk Kita, Jakarta: UNDP. 